\title{
Ecosystem effects of fishing closures in mangrove estuaries of tropical Australia
}

\author{
Janet A. Ley ${ }^{1, *}$, Ian A. Halliday ${ }^{2}$, Andrew J. Tobin ${ }^{3}$, Rod N. Garrett ${ }^{4}$, Neil A. Gribble ${ }^{4}$ \\ ${ }^{1}$ Australian Institute of Marine Science, PMB No. 3, Townsville, Queensland 4810, Australia \\ ${ }^{2}$ Queensland Department of Primary Industries, PO Box 76, Deception Bay, Queensland 4508, Australia \\ ${ }^{3}$ Queensland Department of Primary Industries, PO Box 1085, Townsville, Queensland 4801, Australia \\ ${ }^{4}$ Queensland Department of Primary Industries, PO Box 5396, Cairns, Queensland 4870, Australia
}

\begin{abstract}
Along the section of Australia's coast adjacent to the Great Barrier Reef, certain mangrovedominated estuaries have been closed to commercial net fishing for over 5 yr. During a 2 yr bimonthly sampling program aimed at evaluating the effect of these closures, fish communities were compared among 3 pairs of neighbouring estuaries ( 1 closed and 1 open to commercial net fishing per pair). We employed a complete factorial design to test effects of fishing (open or closed), region of the study area along the coast of Queensland (north, middle or south), and position (upstream or downstream). Standardised sets of gill nets (19 to $152 \mathrm{~mm}$ stretched mesh) were used, with the largest-mesh research nets $(152 \mathrm{~mm})$ comparable to smallest mesh $(150 \mathrm{~mm})$ nets permitted for commercial gill net fishing within open estuaries. In comparison with open systems, catch rates in the largest-mesh research nets in closed systems were 3 times greater for total abundance, 3.7 times greater for the main target species barramundi Lates calcarifer (Centropomidae), 4.4 times greater for juvenile sharks Carcharhinus leucas (Carcharhinidae), and 2.9 times greater for queenfish Scomberoides commersonianus (Carangidae). Furthermore, in comparison with open systems, catch rates in $102 \mathrm{~mm}$ mesh research nets in closed systems were 2.5 times greater for L. calcarifer. While lower catch rates of target and bycatch species in $152 \mathrm{~mm}$ mesh nets could be readily attributed to commercial operations in open systems, reasons for lower catch rates in the $102 \mathrm{~mm}$ research nets were less apparent, since gill nets with $<150 \mathrm{~mm}$ mesh were prohibited within the open estuaries. Reduction in numbers of large barramundi may have had an impact on recruitment of juveniles in the fished estuaries, leading to these lower catch rates in smaller size classes. Despite substantial depletion in numbers of piscivorous predators in fished systems, there was no evidence of impacts on lower trophic levels sampled with the 2 smallestmesh research nets (51 $\mathrm{mm}$ and multipanel 19/25/35 mm mesh). In these estuaries, prey species assemblages were comprised of 92 species, mainly planktivores, scavengers and detritivores. As in coral reef systems, high diversity and productivity in tropical mangrove-dominated estuaries may strengthen the resilience of prey-base communities to disturbances such as fishing. However, since substantially greater abundances of target and bycatch species occurred among replicate mangrove estuaries protected from commercial fishing, our results significantly strengthen the case in favour of the effectiveness of reserves in conserving populations of exploited species.
\end{abstract}

KEY WORDS: Marine reserves · Factorial design - Tropical estuaries · Effects of fishing · Mangroves · Biodiversity $\cdot$ Centromopidae $\cdot$ Lates calcarifer $\cdot$ Trophic cascade

\section{INTRODUCTION}

Throughout the world there is growing public debate about the effects of fishing on ecosystem biodi-

${ }^{*}$ Present address: Australian Maritime College, PO Box 21, Beauty Point, Tasmania 7270, Australia.

Email: j.ley@fme.amc.edu.au versity. Maintaining biotic diversity is a primary objective in aquatic ecosystem and fisheries management because this property is thought to confer ecosystem resilience in the face of changing environmental conditions and human exploitation (Jennings \& Kaiser 1998, Worm et al. 2002). However, a major constraint to developing and evaluating an ecosystem-based approach to marine-resource management is that the

(C) Inter-Research $2002 \cdot$ www.int-res.com 
dynamics of aquatic systems are so complex and poorly known that predictions of the results of a particular management intervention are usually very uncertain (Lauck et al. 1998, Sainsbury et al. 2000). Thus, a critical step in the process of establishing effective measures based on ecological sustainability is to acquire objective scientific information about effects of exploitation on critical ecosystem components.

Surprisingly little published information is available that documents impacts of exploitation on estuarine fish communities. Recently, Johnson et al. (1999) compared fish populations in no-take zones with fished areas of an estuary in eastern Florida, USA. Using large-mesh trammel nets, these investigators netted relatively greater abundances of gamefish, particularly in larger size classes, in unfished areas. Their survey and tagging results indicate that long-term no-take reserves are effective at protecting exploitable species from fishing depletion, and provide fish to support surrounding fisheries (Roberts et al. 2001). Such results are consistent with those from earlier investigations that incorporated fishery-independent surveys to identify the direct effects of line fishing on target fish communities of coral reefs by comparing fished versus unfished reefs (e.g. Russ \& Alcala 1989, Wantiez et al. 1997).

Indirect effects of fishing closures on species diversity and composition of fish communities may be evident under certain circumstances, as fishing is known to disrupt aquatic food webs (Pauly et al. 2000). Day et al. (1989) suggest that if top level consumers are removed by fishing, trophic effects may be conveyed to other species (prey, competitors), thereby generating changes throughout the ecosystem. Such cascading effects have been empirically demonstrated for temperate lacustrine fish communities (Carpenter et al. 1985), as well as for streams and rivers (Power et al. 1985, Power 1990). However, in several tests based on coral-reef fish communities, even with significant decreases in abundances of piscivorous species caused by targeted fishing, no corresponding changes could be detected in abundances of non-target biota (see Jennings \& Kaiser 1998). Effects of fishing may be more pronounced in temperate freshwater systems than on coral reefs because reef fish communities are more diverse (Jennings \& Kaiser 1998). A comprehensive sampling approach is necessary to investigate the effects of fishing on a wide range of ecosystem components and, to our knowledge, no such studies have been conducted to date for estuarine systems.

The geography of coastal Queensland, Australia (Fig. 1) provided the opportunity to study the effects of fishing in multiple estuarine systems, including several that had been closed to all commercial net fishing for at least 5 yr. Interspersed among these closed estuaries were others that remained open to commercial net fishing. Closed and open systems existed in close enough proximity to one another (within $100 \mathrm{~km}$ ) to be paired for comparison purposes. This circumstance made it possible to overcome one of the problems often inherent in comparative studies of fished versus unfished systems - lack of statistically valid replication (see Allison et al. 1998). Additionally, along the same stretch of the north Queensland coast between Cairns and Bowen, a dramatic transition occurred between mountainous, tropical rainforest-dominated catchments of rivers in the north, and low-lying drier eucalypt forested catchments further south. By conducting paired comparative surveys within relatively homogeneous regions in this area, it was possible to overcome one of the other major problems associated with quantifying effects of fishing closures-identification of fishing impacts aside from climatic and habitat variation (Blaber et al. 2000). Because of diversity among regions, any effects of fishing identified in our study would be observed over a range of habitat and environmental conditions.
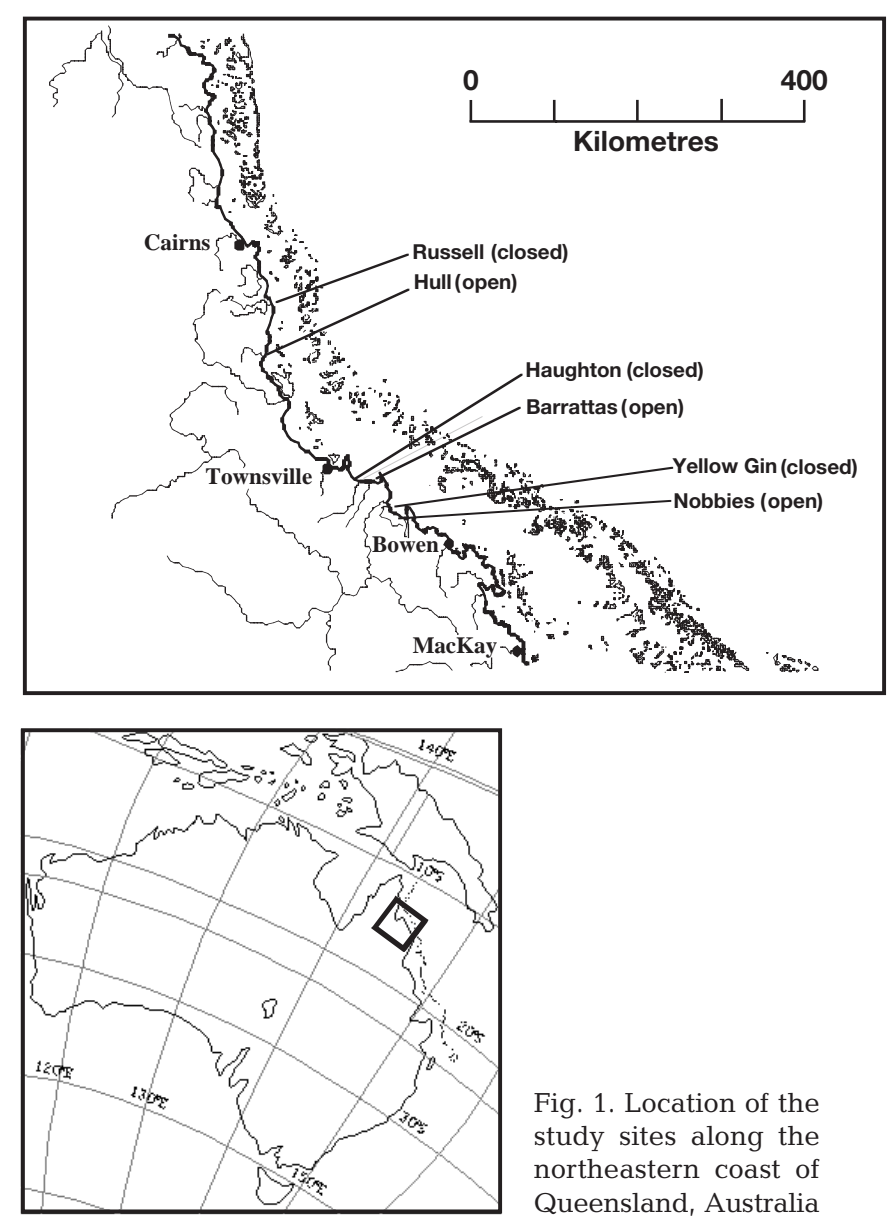

Fig. 1. Location of the study sites along the northeastern coast of Queensland, Australia 
The primary species targeted by commercial netfishers throughout the study area is barramundi Lates calcarifer (Centropomidae). This fishery has been characterized as a resource under pressure based on declining catch rates along the Queensland east coast (Williams 1997). Sustaining barramundi populations depends on both managing the fishery and protecting estuarine habitat. Adults spawn around river mouths, and larval and juvenile barramundi occupy nearby marine wetlands. Juveniles then move into freshwater habitats to grow for 1 or 2 yr (Williams 1997). Barramundi initially breed as males (2 to $6 \mathrm{yr}$ old) and subsequently as females (>6 yr old) (Davis 1986). Species whose life cycle includes a change of sex represent a particular challenge to fisheries managers because of the need to protect both young and old fish (i.e. both sexes) from overfishing (Bohnsack 1993, Milton et al. 1998). Barramundi populations can suffer if fishing removes numerous larger female fish, which are highly fecund and vital in sustaining egg production. Thus, fishing could have direct effects on populations when removing larger females and when removing males before they have had a chance to breed.

Here we describe fishery independent sampling surveys in 6 riverine estuaries located in tropical northeastern Queensland, 3 that were closed to commercial net fisheries and 3 that were open. We tested the hypothesis that removal of fishes by commercial net fishing would have both direct and indirect effects on fish communities in the estuarine ecosystems under study, as indicated by differences in species diversity and abundance patterns between open and closed systems.

\section{MATERIALS AND METHODS}

Study area. The study area extends $350 \mathrm{~km}$ along the northeastern Queensland coast (from $17^{\circ} 14^{\prime} \mathrm{S}, 145^{\circ} 58^{\prime} \mathrm{E}$ to $19^{\circ} 50^{\prime} \mathrm{S}, 147^{\circ} 45^{\prime} \mathrm{E}$ ) (Fig. 1). Marked changes in climate and geomorphology occur from north to south across the area. Annual rainfall averages over $4000 \mathrm{~mm}$ in the north but less than $1000 \mathrm{~mm}$ in the south. Because the Great Dividing Range (maximum elevation $1700 \mathrm{~m}$ ) is in closer proximity to the coast in the north, coastal rivers flow through mountainous rainforest catchments; in contrast, more southern rivers flow through broad, flat eucalyptus forests and bush lands. Finally, the Great Barrier Reef lies less than $10 \mathrm{~km}$ offshore in the north, but in the south the Reef lies at least $50 \mathrm{~km}$ offshore.

Fishing policy under Queensland's Fisheries Act 1994 permits recreational line-fishing in riverine estuaries throughout the area. Commercial fishing is also permitted, subject to limited-entry requirements and other restrictions. Licensed commercial fishers may set gill nets in riverine estuaries if stretched-mesh sizes are between 150 and $215 \mathrm{~mm}$. Finer mesh (50 mm) haul seines may also be deployed in estuaries by a few commercial fishers. In addition, smaller mesh (100 to $215 \mathrm{~mm}$ mesh) gill nets may be set along foreshores adjacent to estuary entrances. Commercial netting is prohibited in rivers and along foreshores during the spawning season for barramundi (1 November to 1 February). In addition, in recent years, 9 riverine estuaries in the region have been closed to all forms of commercial net fishing to conserve fishery resources. Effectiveness of these closures has not been evaluated to date.

We selected 3 pairs of estuaries such that each pair represented 1 of 3 arbitrary regions across the north to south landscape gradient. Each pair included one estuary open to commercial net fishing ('open'), and one estuary which had been closed to commercial net fishing for at least 5 yr ('closed'). All systems had welldeveloped mangrove shorelines, including Avicennia marina, Rhizophora stylosa, and Ceriops spp. Member systems within each pair were selected so that both were similar in terms of: (1) river catchment and outfall embayment, (2) length and direction of main channel, (3) land elevations and terrestrial habitat, and (4) extent of mangrove wetlands. Although sampling was confined to the mangrove-dominated portion of the riverine estuary, systematic changes in habitat conditions were observed along the upstream to downstream estuarine gradient. Extensive mangrove wetlands occurred near the mouth, narrowing to a fringe of mangrove trees along the river bank further upstream when the main sources of freshwater inflow to the systems were approached. Downstream, near the mouth, the estuaries were shallow and broad ( $>1 \mathrm{~km}$ wide) with many sinuous branches; upstream, river channels were relatively narrow $(<100 \mathrm{~m})$ and deep $(>5 \mathrm{~m})$. Sampling sites were selected both upstream (5 to $10 \mathrm{~km}$ from the mouth) and downstream (within $1 \mathrm{~km}$ of the mouth) in each system.

A bimonthly sampling schedule was chosen to investigate effects of seasonality. This tropical region has a rainy season (November to February), with drier conditions throughout the remainder of the year. Semi-diurnal tidal cycles prevail, ranging from less than $2 \mathrm{~m}$ on neap tides to $4 \mathrm{~m}$ on spring tides. Because effectiveness of gill nets can be strongly influenced by tidal conditions, sampling of the 6 estuaries was conducted consecutively over $7 \mathrm{~d}$ within the period of weakest neap tides $(0.5$ to $1.8 \mathrm{~m}$ range). The sequence of pairs was re-ordered among trips so that each was sampled at the full range of near-neap conditions. 
Sampling procedures. Mesh sizes and hanging ratios of the sampling nets were designed to capture fish having a wide range of body morphologies. Two identical groups of monofilament gillnets were used to enable upstream and downstream sampling to be conducted simultaneously. Each group of nets consisted of $2 \times 152 \mathrm{~mm}$ stretched mesh nets (length $38.5 \mathrm{~m}$, depth $4.6 \mathrm{~m}$ ), $2 \times 102 \mathrm{~mm}$ mesh nets (length $21.2 \mathrm{~m}$, depth $4.7 \mathrm{~m}$ ), together with a single $51 \mathrm{~mm}$ mesh net (length $24.1 \mathrm{~m}$, depth $2.2 \mathrm{~m}$ ) and a smaller mesh multi-panel net (length $38.1 \mathrm{~m}$, depth 1.5 to $2.5 \mathrm{~m}$ ). Multi-panel nets had 3 panels of 19, 25 and $32 \mathrm{~mm}$ mesh joined end to end to make one continuous net.

Replicate 102 and $152 \mathrm{~mm}$ mesh nets were set at approximately $15: 00 \mathrm{~h}$ at fixed locations, perpendicular to deep, eroded banks. These large mesh nets were checked hourly and allowed to fish to approximately 21:00 h. To avoid excessively large catches of schooling baitfishes such as clupeids and engraulids, the 51 $\mathrm{mm}$ and multi-panel nets were set for $1 \mathrm{~h}$ either side of dusk. Catch was recorded on each check by species, size and abundance. Most fish that were alive when removed from the nets were measured and released; dead fish and unknown species were retained for later analysis in the laboratory. On rare occasions, net marks indicated that an individual was a re-capture from an earlier check and data were therefore not recorded.

Identifications were made using reference collections at the Australian Institute of Marine Science (AIMS) and various literature sources (e.g. Munro 1967, Allen 1997, Grant 1997, Randall et al. 1997). Specimens weighed in the laboratory were used to generate a series of equations for each species fitted to the power curve:

$$
W=\mathrm{q} L^{\mathrm{b}}
$$

where $W=$ weight, $L=$ length, and $\mathrm{q}$ and $\mathrm{b}$ are constants. Biomass was calculated using these equations, supplemented with data from previous AIMS collections and FishBase (R. Froese, D. Pauly [eds] 2002, species summary for Liza vaigiensis, squaretail mullet; available at: www.fishbase.org).

Throughout the net-soak period, aquatic conditions were measured at 5 min intervals using 1 or 2 Hydrolab Datasonds. Salinity, temperature, dissolved oxygen, water level and $\mathrm{pH}$ were recorded near the netdeployment sites.

Statistical analysis. As each mesh used in the study most effectively targeted a particular segment of the fish populations, analyses were conducted separately for each net type. The experimental design was a complete factorial structure with 3 geographical regions (north, middle, south), 2 policies regarding commercial net fishing (open and closed), 2 positions along the estuarine gradient (upstream and downstream), 13 points in time (2 year bimonthly sampling program), with 2 replicate nets deployed each time. Thus, each sample represented one night's set of an individual net, making a total of 312 samples per net. All interactions up to 3-way were estimated. Key variables were chosen for analysis: diversity indices (see below), number of species, catch and biomass of all species combined, and catch of 20 selected species representing the 5 most abundant species for each net type.

Prior to analyses, catch rate (fish sample ${ }^{-1}$ ) and total number of species per sample were $\ln (x+0.5)$ transformed (Yamamura 1999). Biomass data (g sample ${ }^{-1}$ ) were $\sqrt{x+0.5}$ transformed. Since split-plot analyses of repeated measures over time (using AREPMEASURES in Genstat, Payne et al. 1993) showed a consistent degree of autocorrelation, a constant correction factor $(\varepsilon=0.35)$ was applied to the degrees of freedom for time related factors (Greenhouse \& Geisser 1959). For the final model, the covariate soak time was added. Calculations of diversity indices were made using the following formulae (Zar 1999):

$\begin{array}{ll}\text { Margalef Species Richness Index } & d=(S-1) / \ln N \\ \text { Shannon-Wiener Diversity Index } & H^{\prime}=-\sum_{i} p_{i}\left(\ln p_{i}\right) \\ \text { Pielou's Evenness Index } & J^{\prime}=H_{\text {observed }}^{\prime} / H_{\text {max }}^{\prime}\end{array}$

where $S=$ number of species, $N=$ number of individuals, and $p_{i}=$ proportion of total species count arising from the $i$ th species. $\ln (S)=\left(H_{\text {max }}^{\prime}\right)$ represents maximum diversity.

Multivariate analyses used to identify patterns in species distribution among sites $(n=12)$ were facilitated by the computer software package PRIMER (Version 5.2.2). For each net type, average abundance of the 20 most abundant species were square-root transformed and used to generate similarity matrices and cluster groups based on the Bray-Curtis index. Spatial relationships among groups were viewed using multidimensional scaling (MDS). If the MDS stress level was $<0.20$, plots were inspected for possible influences of the 3 main effects (region, fishing, and position). Significance of these spatial groups was tested using 1-way analysis of similarities (ANOSIM). SIMPER analyses identified which species were responsible for distinguishing spatial groups. For each species, SIMPER calculates the ratio of (1) average contribution to similarity between groups to (2) standard deviation of similarity between groups. The higher the value of the discrimination index, the more useful the species is for discriminating between groups (Clarke \& Warwick 1994).

Lastly, we tested differences in median fish length between open and closed areas for 7 species that are commonly marketed. We used the Mann-Whitney $U$-test for this analysis because the data had a nonnormal distribution (Statsoft 1995). 
Table 1. Total catch by family for all nets combined (order and naming following Nelson 1994) in systems closed and open to commercial fishing

\begin{tabular}{|c|c|c|c|}
\hline Family & Common name & Closed & Open \\
\hline Carcharhinidae & Requiem sharks & 137 & 33 \\
\hline Sphyrnidae & Hammerhead sharks & & 3 \\
\hline Rhinobatidae & Guitarfish & 1 & 1 \\
\hline Dasyatidae & Stingrays & 4 & 1 \\
\hline Myliobatidae & Eagle rays & 1 & 5 \\
\hline Elopidae & Ladyfishes & 25 & 38 \\
\hline Megalopidae & Tarpons & 125 & 83 \\
\hline Muraenesocidae & Pike congers & 2 & \\
\hline Engraulidae & Anchovies & 1249 & 1197 \\
\hline Chirocentridae & Wolf herrings & 7 & 8 \\
\hline Clupeidae & Herrings & 4875 & 4073 \\
\hline Chanidae & Milkfishes & 25 & 13 \\
\hline Ariidae & Sea catfishes & 1112 & 1032 \\
\hline Plotosidae & Eeltail catfishes & & 11 \\
\hline Batrachoididae & Toadfishes & 4 & \\
\hline Mugilidae & Mullets & 1597 & 1113 \\
\hline Atherinidae & Silversides & & 10 \\
\hline Belonidae & Needlefishes & 199 & 139 \\
\hline Hemiramphidae & Halfbeaks & 151 & 131 \\
\hline Scorpaenidae & Scorpion fishes & 1 & \\
\hline Platycephalidae & Flatheads & 18 & 20 \\
\hline Centropomidae & Snooks/barramundi & 1227 & 430 \\
\hline Ambassidae & Glassfishes & 326 & 366 \\
\hline Serranidae & Sea basses & 2 & 4 \\
\hline Apogonidae & Cardinal fishes & & 2 \\
\hline Sillaginidae & Sand whitings & 54 & 65 \\
\hline Lactariidae & False trevallies & 14 & \\
\hline Echeneidae & Remoras & 2 & \\
\hline Carangidae & Jacks/trevallies & 521 & 193 \\
\hline Leiognathidae & Ponyfishes & 969 & 675 \\
\hline Lutjanidae & Snappers & 37 & 38 \\
\hline Gerreidae & Mojarras & 39 & 40 \\
\hline Haemulidae & Grunters & 406 & 263 \\
\hline Sparidae & Porgies & 15 & 5 \\
\hline Polynemidae & Threadfins & 612 & 257 \\
\hline Sciaenidae & Drums & 195 & 193 \\
\hline Leptobramidae & Beach salmons & 37 & 26 \\
\hline Monodactylidae & Moonfishes & 14 & 4 \\
\hline Toxotidae & Archerfishes & 37 & 28 \\
\hline Drepanidae & Sicklefishes & 72 & 56 \\
\hline Ephippidae & Spade fishes/ batfishes & 1 & 3 \\
\hline Teraponidae & Grunters & 4 & 5 \\
\hline Gobiidae & Gobies & 1 & 1 \\
\hline Scatophagidae & Scats & 34 & 24 \\
\hline Siganidae & Rabbitfishes & 2 & 1 \\
\hline Sphyraenidae & Barracudas & 16 & 32 \\
\hline Trichiuridae & Cutlass fishes & 1 & \\
\hline Scombridae & Mackerels & 32 & 32 \\
\hline Stromateidae & Butterfishes & 7 & \\
\hline Bothidae & Left-eyed flounders & & 1 \\
\hline Soleidae & Soles & 2 & 2 \\
\hline Cynoglossidae & Tongue fishes & 1 & \\
\hline Tetraodontidae & Puffers & 19 & 19 \\
\hline Total & & 14232 & 10676 \\
\hline
\end{tabular}

\section{RESULTS}

\section{Sampling conditions}

With few exceptions, measurements of water conditions were similar between paired systems on every sampling occasion. Overall, water temperatures ranged from 20 to $31^{\circ} \mathrm{C}$, but salinity varied widely (0 to 43 ). Average salinities at downstream sites were lower in the northern systems (17.2), intermediate in the middle region (24.4 to 25.7$)$, and higher in the south (28.2 to 33.6), reflecting the landscape gradient across the study region. More detailed descriptions of site parameters are presented elsewhere (Halliday et al. 2001).

\section{Relative abundance}

In 1248 net sets over the 2 yr sampling period, the research teams netted 24908 fish belonging to 141 species in 53 families. One-third more specimens were netted in closed $(\mathrm{n}=14232)$ than open estuaries $(\mathrm{n}=10676$ ) (Table 1$)$. Only 17 species were common to all 12 sampling sites.

Mesh size and net properties largely determined the length and species composition of individuals sampled (see Halliday et al. 2001). In research gill-nets with the largest mesh size $(152 \mathrm{~mm})$, we netted $7 \%$ of total abundance (1682 fish), 39\% of the total weight (4 t), and 51 species, ranging from 143 to $1520 \mathrm{~mm}$ in length. Centropomids (all barramundi), carangids, polynemids and carcharhinids comprised the greatest proportion of the catch in the $152 \mathrm{~mm}$ mesh nets (Fig. 2a). Members of these 4 families feed at upper trophic levels, and each comprised a greater proportion of the abundance netted with the $152 \mathrm{~mm}$ nets in systems closed to commercial net fishing. In $102 \mathrm{~mm}$ mesh nets, $14 \%$ (5916) of all fish were netted, $53 \%$ of total weight $(5.5 \mathrm{t})$, and 68 species, ranging from 25 to $1430 \mathrm{~mm}$ in length. Mid-level carnivores, detritivores and scavengers (ariids, centropomids, and leiognathids) dominated the catch in these nets (Fig. 2b). The 3560 fish netted in the $51 \mathrm{~mm}$ mesh nets comprised $24 \%$ of all fish caught, $6 \%$ of total weight $(0.6 \mathrm{t})$, and 62 species, ranging from 68 to $1330 \mathrm{~mm}$ in length. Detritivore/herbivores in the family Mugilidae dominated the catch $(42 \%)$ (Fig. 2c). Many species $(\mathrm{n}=92)$ were netted in the multipanel (19/25/32 mm mesh) nets, ranging from 20 to $1250 \mathrm{~mm}$ length. While only $2 \%$ of the overall catch-by-weight was caught in the multipanel nets, the number of fish comprised $55 \%(n=13750)$ of the total numbers from all nets combined. The catch composition was dominated by clupeids (Fig. 2d) with a single clupeid species, Herklotsichthys castelnaui, comprising $54 \%$ of the fish caught in these nets. 

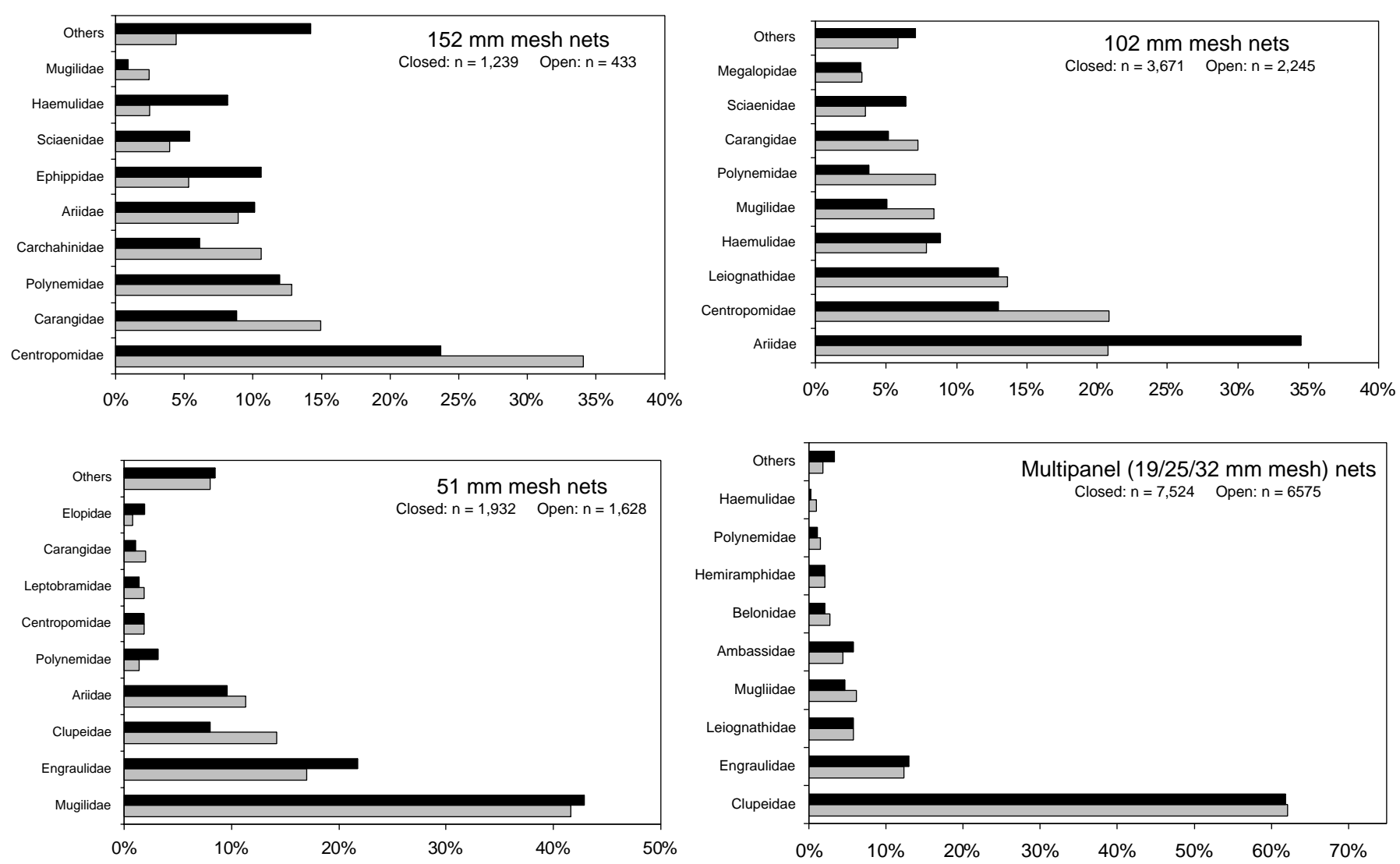

Fig. 2. Family composition of catches in open (black bars) and closed (grey bars) systems. Percentages represent the proportions of the total catch in each net type

\section{Comparison of catch rates}

The largest-mesh research nets $(152 \mathrm{~mm})$ were equivalent to the smallest mesh nets used by commercial gill net fishers in open systems. For this net type, each community parameter was significantly lower in the open systems based on catch of all species combined (Table 2). For example, mean catch rate and mean biomass were 3 and 4 times greater at closed sites, respectively. For each pair, closed sites averaged greater catch rates than their open counterparts (Fig. 3a). Unexpectedly, for the $102 \mathrm{~mm}$ nets, mean catch rate, biomass and diversity were also consistently lower in open systems (Table 2, Fig. 3b). In contrast, for the $51 \mathrm{~mm}$ and multipanel samples, none of the community factors differed significantly between open and closed sites (Table 2).

MDS ordinations for catch rates of the 20 most abundant species caught in the $152 \mathrm{~mm}$ mesh nets resulted in clear differentiation between sites open and closed to commercial fishing (Fig. 4a) ( $p<0.05$, ANOSIM). More detailed analysis (SIMPER) showed that 2 species of carangids (Scomberoides commersonianus, Caranx ignobilis) and Lates calcarifer had the highest discrimination indices (1.57, 1.77 and 1.77 respectively), with greater numbers at closed sites. The multivariate analyses did not reveal any significant differences between open versus closed sites for the other 3 net types. Instead, MDS ordinations and ANOSIM analyses for the $102 \mathrm{~mm}$ mesh catch showed a clear separation between the northern region (G1) and the southern and middle regions combined (G2) ( $<$ < 0.01) (Fig. 4b). Leiognathus equulus, S. tala, and Megalops cyprinoides had the highest discrimination indices $(4.69,3.22,2.13$ respectively) and these species were most abundant in northern sites. Species in the $51 \mathrm{~mm}$ and multipanel nets also separated into 2 main groups based on region (G1 and G2) (Fig. 4c,d).

Comparison of species-specific catch rates revealed significant differences between open and closed systems for 7 species: Carcharhinus leucas, Eleutheronema tetradactylum, Lates calcarifer, Leiognathus equulus, Liza vaigiensis, Polydactylus macrochir, and Scomberoides commersonianus (Table 3). Catch rate in closed systems exceeded open systems for each of these species, but in every case significant interaction terms were identified in the analysis. 

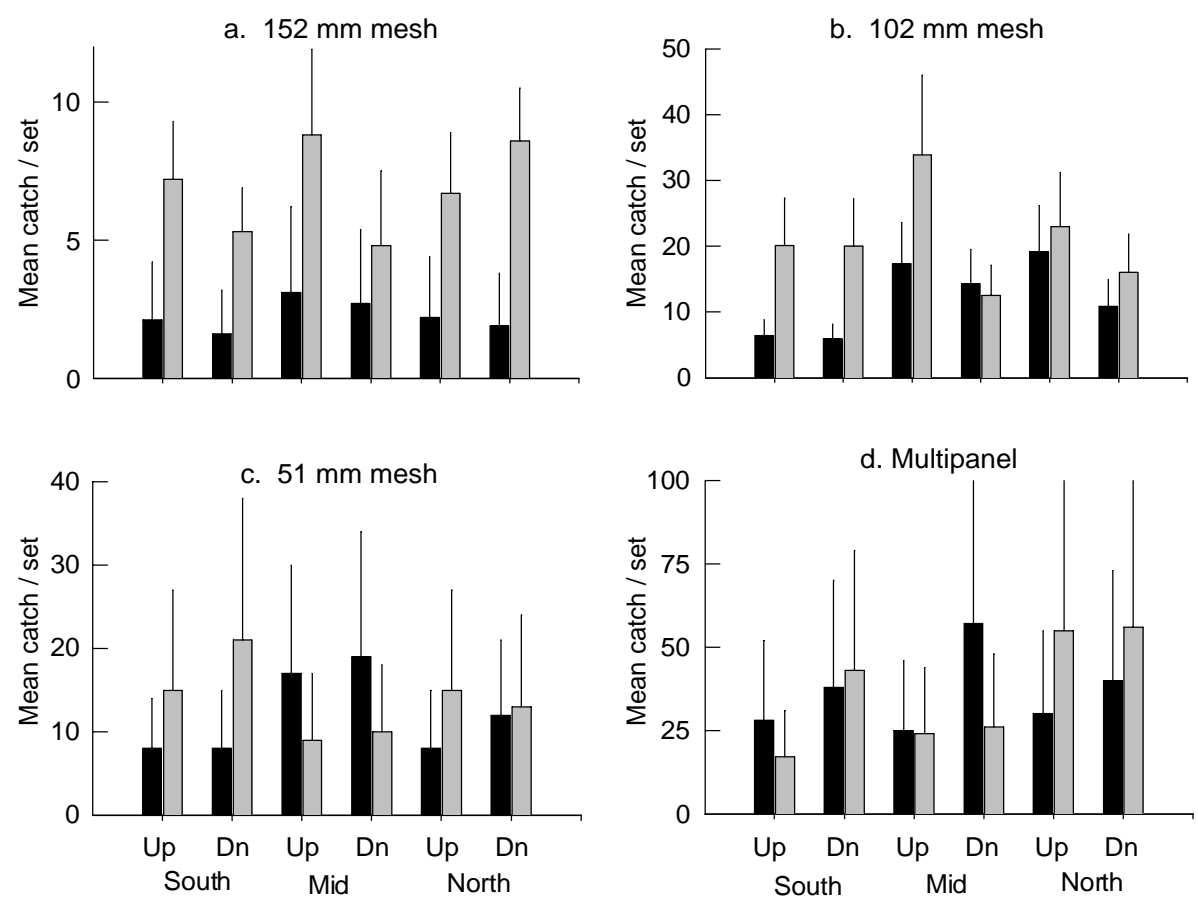

Fig. 3. Mean total catch rates for the 12 sampling sites by type of net in open (black bars) and closed (grey bars) systems. Multipanel net consists of 19/25/32 mm mesh. Error bars represent $95 \%$ confidence intervals (CI). Sampling sites: Up, upstream; Dn, downstream

Table 2. ANOVA results for all species combined per net type; ${ }^{*} \mathrm{p}<0.05_{;}{ }^{* *} \mathrm{p}<0.01$; ${ }^{* * *} \mathrm{p}<0.001$

\begin{tabular}{|c|c|c|c|c|c|}
\hline \multirow{2}{*}{$\begin{array}{l}\text { Net } \\
\text { (mesh size } \\
\text { in } \mathrm{mm} \text { ) }\end{array}$} & \multirow{2}{*}{$\begin{array}{l}\text { Parameters } \\
\text { (mean per set) }\end{array}$} & \multicolumn{2}{|c|}{ Fishing policy } & \multicolumn{2}{|c|}{ Interactions of Fishing with: } \\
\hline & & Open & Closed & $\begin{array}{c}\text { Position } \\
\text { and/or Region }\end{array}$ & $\begin{array}{c}\text { Trip and/or } \\
\text { Position, Region }\end{array}$ \\
\hline \multirow[t]{6}{*}{152} & Catch & 2.2 & $6.7^{* * *}$ & & \\
\hline & Biomass & 4.2 & $16.2^{* * *}$ & $* * *$ & \\
\hline & No. of species & 1.6 & $3.0^{* * *}$ & & \\
\hline & Richness index & 0.7 & $1.0^{* * *}$ & & ** \\
\hline & Diversity index & 0.5 & $0.8^{* * *}$ & & ** \\
\hline & Evenness index & 0.5 & $0.6^{* * *}$ & & * \\
\hline \multirow[t]{6}{*}{102} & Catch & 11.3 & $20.0^{* * *}$ & $* * *$ & \\
\hline & Biomass & 10.8 & $20.9^{* * *}$ & $*$ & \\
\hline & No. of species & 4.5 & $5.9^{* * *}$ & ** & \\
\hline & Richness index & 1.7 & $1.8^{* *}$ & ** & \\
\hline & Diversity index & 1.3 & $1.4^{* *}$ & ** & ** \\
\hline & Evenness index & 0.8 & $0.8^{*}$ & $* * *$ & \\
\hline \multirow[t]{6}{*}{51} & Catch & 11.1 & 13.3 & & \\
\hline & Biomass & 1.9 & 2.1 & & \\
\hline & No. of species & 3.4 & 3.0 & & \\
\hline & Richness index & 1.0 & 0.9 & & \\
\hline & Diversity index & 0.7 & 0.7 & & * \\
\hline & Evenness index & 0.6 & 0.6 & & * \\
\hline \multirow{6}{*}{$\begin{array}{l}\text { Multıpanel } \\
\text { (19/25/32) }\end{array}$} & Catch & 35.2 & 33.5 & & \\
\hline & Biomass & 0.8 & 0.7 & & \\
\hline & No. of species & 5.6 & 5.1 & & \\
\hline & Richness index & 1.2 & 1.1 & & \\
\hline & Diversity index & 0.9 & 0.8 & & \\
\hline & Evenness index & 0.6 & 0.5 & & \\
\hline
\end{tabular}

In the $152 \mathrm{~mm}$ mesh nets, Carcharhinus leucas catch rates for closed sites averaged 4.4 times greater than open sites $(\mathrm{p}<0.001)$ (Table 3). For 5 of the 6 paired sites, mean catch rates were greater in the closed sites than in the corresponding open sites. The total catch in closed systems exceeded that in open systems for all size classes (Fig. 5a,b).

For Eleutheronema tetradactylum caught in the 152 and $102 \mathrm{~mm}$ mesh nets, catch rates at closed sites were 1.5 times greater than at open sites ( $p<0.05)$ (Table 3$)$. However, further analysis revealed inconsistencies in this trend. Specifically, catch rates of E. tetradactylum were very high at the closed upstream southern site in winter, but otherwise catch rates were low and differed little between open and closed sites (Fig. 6a,c). Interestingly, the 400 to $500 \mathrm{~mm}$ length class was the most prevalent size caught in both 102 and $152 \mathrm{~mm}$ mesh research nets, indicating significant overlap between mesh sizes in catchability of this species (Fig. 6b,d).

In the $152 \mathrm{~mm}$ mesh nets, mean catch rate of Lates calcarifer at closed sites was 3.7 times greater than open sites $(p<0.001)$ (Table 3$)$. Furthermore, mean catch rate in the $102 \mathrm{~mm}$ mesh nets at closed sites was 2.5 times greater than at open sites $(p<0.001)$. These trends were consistent, with catch at closed sites exceeding open sites in all 6 pairs (Fig. $7 \mathrm{a}, \mathrm{c}$ ). There was little overlap between the 152 and $102 \mathrm{~mm}$ mesh nets in size classes of barramundi captured. Sampling with $152 \mathrm{~mm}$ mesh research nets captured the greatest numbers in the 601 to $800 \mathrm{~mm}$ length class (Fig. 7b), indicating that few barramundi of less than legal size $(580 \mathrm{~mm})$ were caught in the $152 \mathrm{~mm}$ mesh nets. In contrast, the $102 \mathrm{~mm}$ nets effectively sampled individuals in the 401 to 600 size classes (Fig. 7d). 

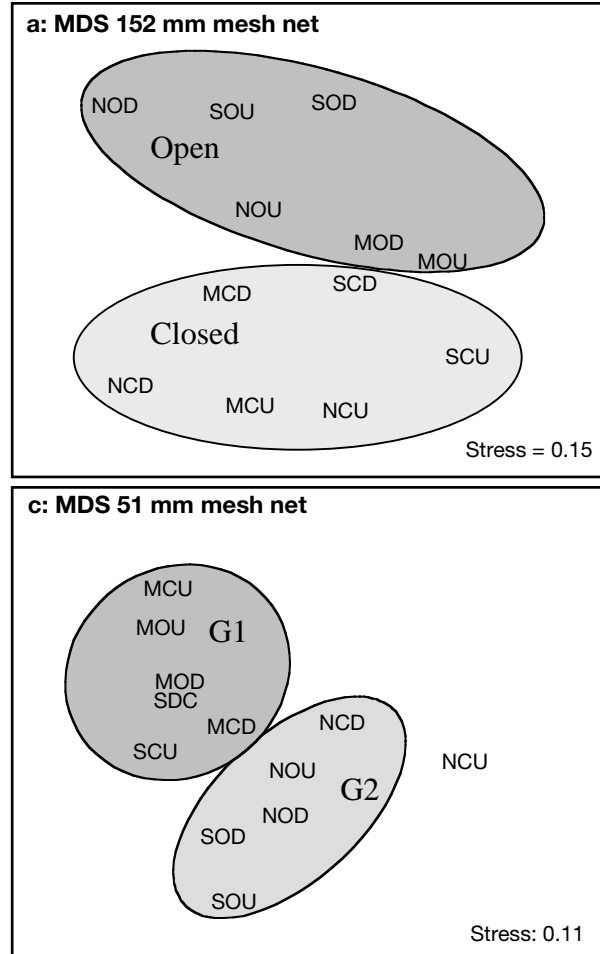

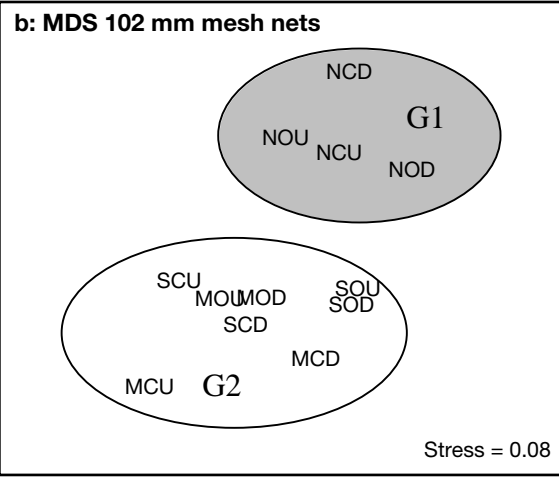

d: MDS multipanel nets

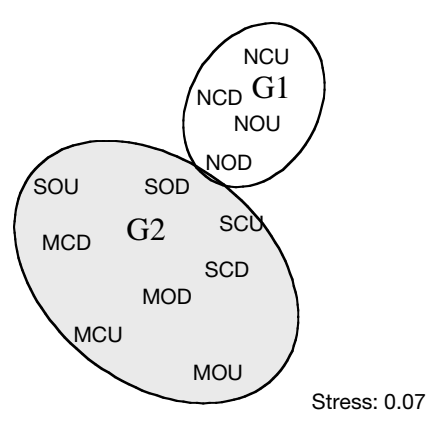

Fig. 4. Multidimensional scaling (MDS) ordinations of 12 sites based on the 20 most abundant species for each net type; multipanel net consists of 19/25/32 mm mesh. The 3 letter codes are: 1st letter for region, $\mathrm{N}=$ north, $\mathrm{M}=$ mid, $\mathrm{S}=$ south; 2 nd letter for fishing policy, $\mathrm{O}=$ open, $\mathrm{C}=$ closed; 3rd letter for position $U=$ upstream, $\mathrm{D}=$ downstream

Table 3. ANOVA results for the top 5 species by abundance for each mesh size. The names of commercial species are shown in bold. ${ }^{*} \mathrm{p}<0.05 ;{ }^{* *} \mathrm{p}<0.01 ;{ }^{* * *} \mathrm{p}<0.0001$

\begin{tabular}{|c|c|c|c|c|c|c|}
\hline \multirow[t]{2}{*}{ Species } & \multirow{2}{*}{$\begin{array}{l}\text { Net mesh } \\
(\mathrm{mm})\end{array}$} & \multirow{2}{*}{$\begin{array}{l}\text { Total } \\
\text { catch }\end{array}$} & \multicolumn{2}{|c|}{ Mean catch per set } & \multicolumn{2}{|c|}{ Interactions of Fishing with: } \\
\hline & & & Open & Closed & $\begin{array}{c}\text { Position } \\
\text { and/or Region }\end{array}$ & $\begin{array}{c}\text { Trip and/or } \\
\text { Position, Region }\end{array}$ \\
\hline Carcharhinus leucas & 152 & 144 & 0.07 & $0.31^{* * *}$ & ** & $* *$ \\
\hline Eleutheronema tetradactylum & $\begin{array}{l}152 \\
102\end{array}$ & $\begin{array}{l}143 \\
297\end{array}$ & $\begin{array}{l}0.21 \\
0.45\end{array}$ & $\begin{array}{l}0.33^{*} \\
0.68^{*}\end{array}$ & $\stackrel{*}{*}$ & $\stackrel{* *}{* * *}$ \\
\hline Lates calcarifer & $\begin{array}{l}152 \\
102\end{array}$ & $\begin{array}{r}527 \\
1057\end{array}$ & $\begin{array}{l}0.41 \\
1.07\end{array}$ & $\begin{array}{l}1.50^{* * *} \\
2.67^{* * *}\end{array}$ & $\stackrel{* * *}{*}$ & * \\
\hline Scomberoides commersonianus & $\begin{array}{l}152 \\
102\end{array}$ & $\begin{array}{l}140 \\
192\end{array}$ & $\begin{array}{l}0.11 \\
0.19\end{array}$ & $\begin{array}{l}0.32^{* * *} \\
0.56^{* * *}\end{array}$ & $\stackrel{* * *}{* *}$ & $\stackrel{* * *}{*}$ \\
\hline Leiognathus equulus & 102 & 785 & 0.63 & $0.79^{*}$ & * & * \\
\hline Liza vaigiensis & 102 & 256 & 0.43 & $0.86^{* *}$ & & $* *$ \\
\hline Polydactylus macrochir & 102 & 102 & 0.08 & $0.21^{* * *}$ & $* * *$ & $* * *$ \\
\hline Pomadasys argenteus & 102 & 247 & 0.44 & 0.56 & & \\
\hline Pomadasys kaakan & 102 & 232 & 0.61 & 0.65 & & \\
\hline Arius spp. & $\begin{array}{r}152 \\
102 \\
51\end{array}$ & $\begin{array}{r}156 \\
1507 \\
374\end{array}$ & $\begin{array}{l}0.21 \\
2.57 \\
0.93\end{array}$ & $\begin{array}{l}0.31 \\
2.70 \\
1.07\end{array}$ & & \\
\hline Nibea soldado & 102 & 271 & 0.90 & 0.77 & & \\
\hline Liza subviridis & 51 & 518 & 1.38 & 1.63 & & \\
\hline Valamugil cunnesius & 51 & 552 & 2.15 & 2.71 & & \\
\hline Valamugil buchanani & 51 & 272 & 0.35 & 0.27 & & \\
\hline Valamugil seheli & 51 & 119 & 0.27 & 0.19 & & \\
\hline Ambassis vachelli & $\mathrm{Mp}$ & 536 & 2.37 & 1.99 & & \\
\hline Herklotsichthys castelnaui & Mp & 7414 & 11.66 & 12.12 & & \\
\hline Nematalosa come & Mp & 457 & 0.86 & 0.55 & & \\
\hline Thryssa hamiltoni & $\mathrm{Mp}$ & 1561 & 13.20 & 11.25 & & \\
\hline
\end{tabular}


Fig. 5. Carcharhinus leucas. Catch in $152 \mathrm{~mm}$ mesh nets in open (black bars) and closed (grey bars) systems: (a) mean catch rates with $95 \%$ CI by sampling site; (b) total catch by length class. TL: total length. Up: upstream; Dn: downstream
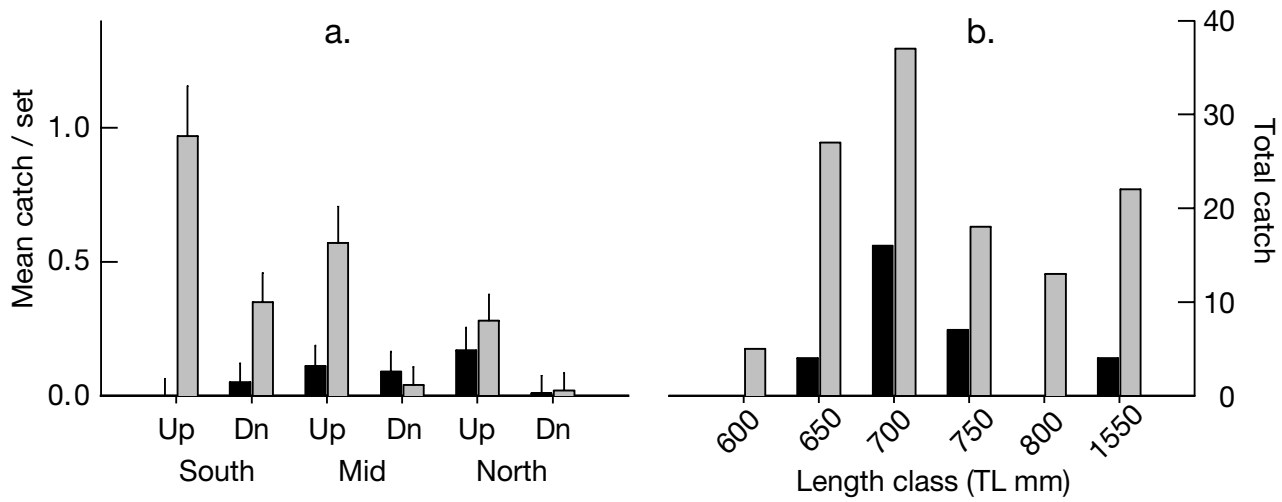

Mean catch rate of Scomberoides commersonianus in 152 and $102 \mathrm{~mm}$ mesh nets at closed sites was 3 times greater than open sites $(p<0.001)$ (Table 3$)$. This trend was consistent, as closed sites exceeded open sites for most pairs (Fig. 8a,c). There was little overlap between the $152 \mathrm{~mm}$ and $102 \mathrm{~mm}$ mesh nets in size classes of queenfish captured (Fig. 8b,d).

For Leiognathus equulus, mean catch rate in $102 \mathrm{~mm}$ mesh nets for closed sites was somewhat greater than for open sites $(\mathrm{p}<0.05)$ (Table 3$)$. However, closed sites exceeded open in only 2 of the 6 paired comparisons, and both of these sites were in the northern region (Fig. 9a). Only 3 of the 785 specimens of this species netted in the $102 \mathrm{~mm}$ mesh nets were captured outside of the 2 northern systems. In contrast, mean catch rate of Liza vaigiensis in the $102 \mathrm{~mm}$ nets at closed sites was 2 times greater than open sites $(\mathrm{p}<0.01)$ and closed sites exceeded open in all 6 pairs (Table 3, Fig. 10a).

Mean catch rate of Polydactylus macrochir in $102 \mathrm{~mm}$ nets at closed sites was 2.6 times greater than for open sites $(p<0.001)$, and closed sites exceeded open in 5 of the 6 paired comparisons (Table 3, Fig. 11a,c). Even though relatively low numbers were caught in the $152 \mathrm{~mm}$ nets $(\mathrm{n}=69)$, trends are presented for the purpose of making graphical comparisons (Fig. 11c,d). All specimens caught in $152 \mathrm{~mm}$ nets and $90 \%$ of those caught in $102 \mathrm{~mm}$ nets exceeded the legal limit (400 mm) with a great deal of overlap among size classes of king threadfin caught in the 2 net types (Fig. 11 b,d).
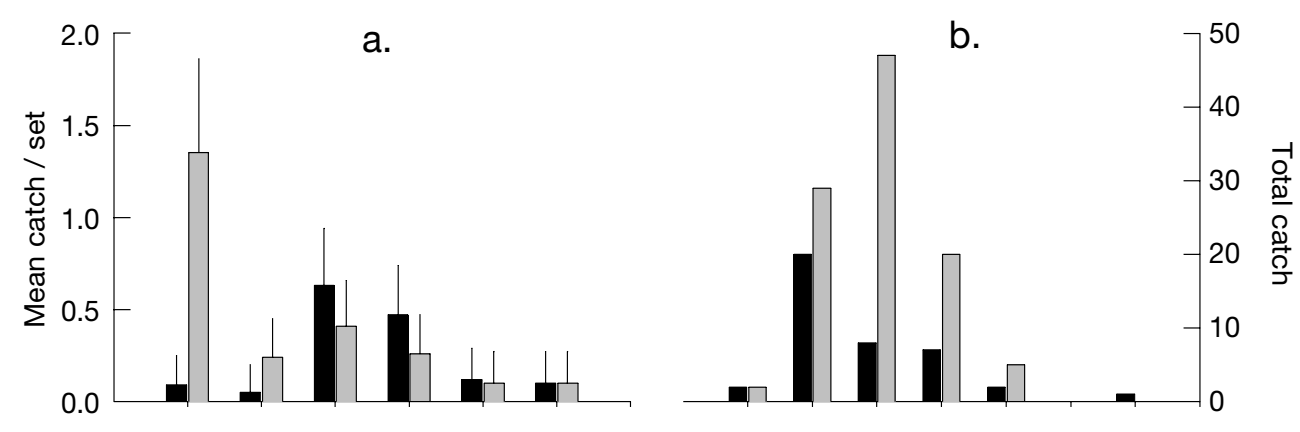

Fig. 6. Eleutheronema tetradactylum. Catches in open (black bars) and closed (grey bars) systems: (a) mean catch rates with $95 \% \mathrm{CI}$ by sampling site for $152 \mathrm{~mm}$ mesh nets; (b) total catch by length class for $152 \mathrm{~mm}$ mesh nets; (c) mean catch rates with $95 \% \quad \mathrm{CI}$ for $102 \mathrm{~mm}$ mesh nets; (d) total catch by length class for $102 \mathrm{~mm}$ mesh nets. FL: fork length; Up: upstream; Dn: downstream
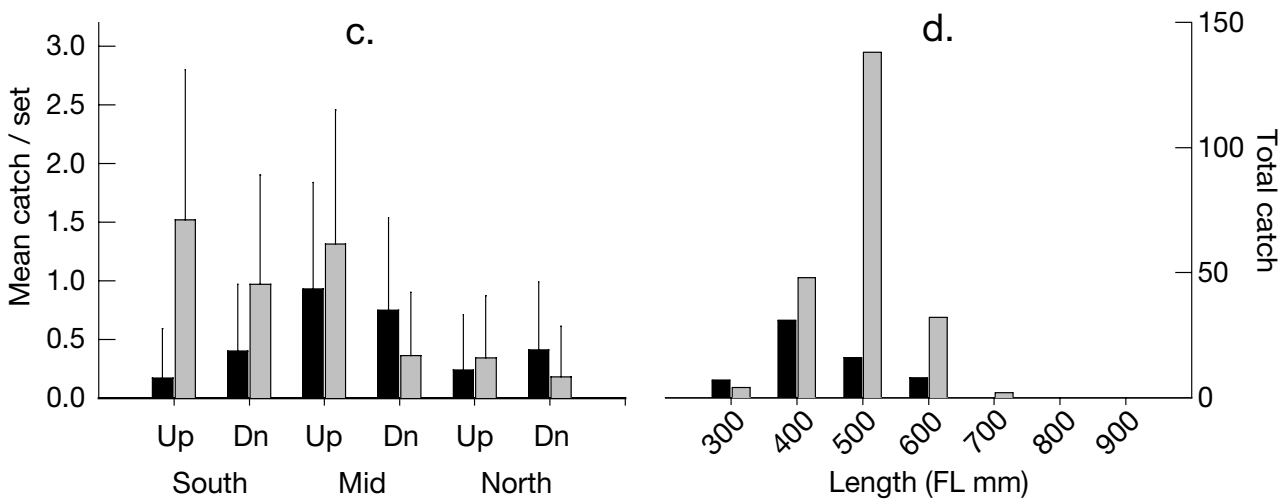


\section{Average length}

Of the 7 species which are marketed, Eleutheronema tetradactylum, Lates calcarifer, and Scomberoides commersonianus specimens were significantly smaller in the open systems $(\mathrm{p}<0.001)$ (Table 4$)$. For 3 other species tested, median size classes were not significantly different between open and closed rivers, while 1 species was somewhat larger in the open systems (Pomadasys kaakan).
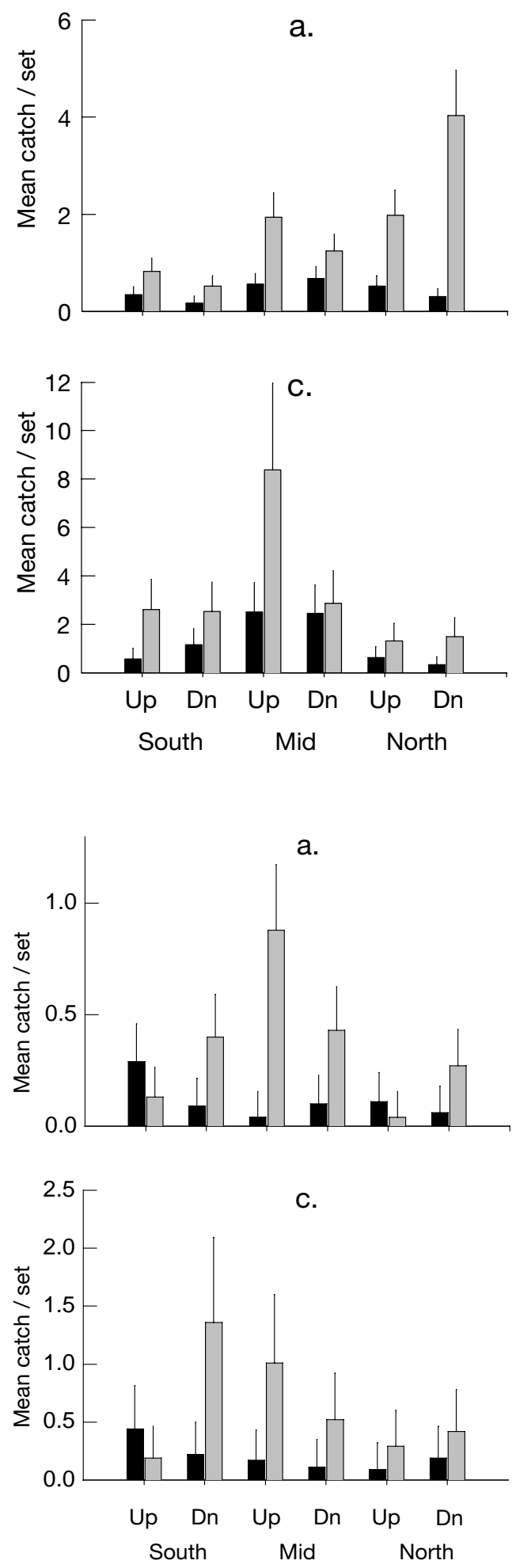
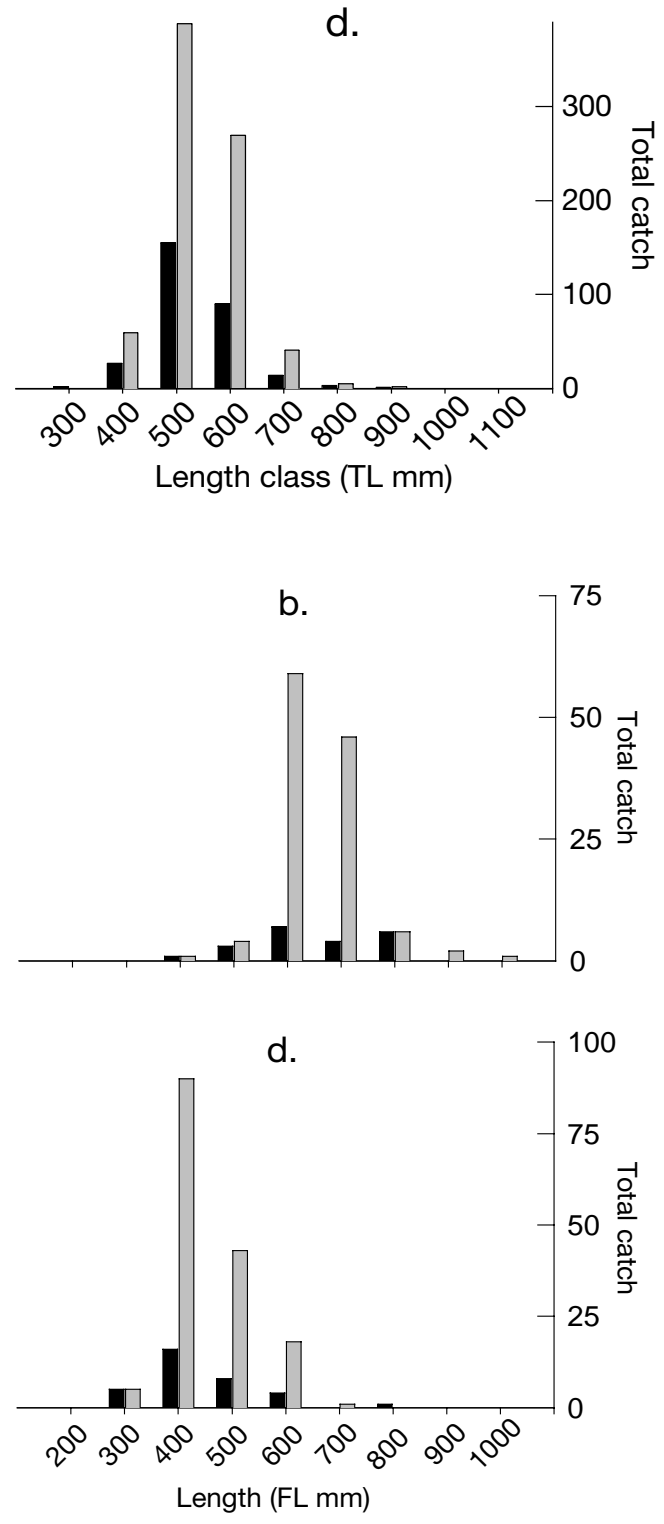

Fig. 7. Lates calcarifer. Catches in open (black bars) and closed (grey bars) systems: (a) mean catch rates with $95 \%$ CI by sampling site for $152 \mathrm{~mm}$ mesh nets; (b) total catch by length class for $152 \mathrm{~mm}$ mesh nets; (c) mean catch rates with 95\% CI for $102 \mathrm{~mm}$ mesh nets; (d) total catch by length class for $102 \mathrm{~mm}$ mesh nets. TL: total length; Up: upstream; Dn: downstream
Fig. 8. Scomberoides commersonianus. Catches in open (black bars) and closed (grey bars) systems: (a) mean catch rates with $95 \%$ CI by sampling site for $152 \mathrm{~mm}$ mesh nets; (b) total catch by length class for $152 \mathrm{~mm}$ mesh nets; (c) mean catch rates with $95 \%$ CI for $102 \mathrm{~mm}$ mesh nets; (d) total catch by length class for $102 \mathrm{~mm}$ mesh nets. FL: fork length; Up: upstream; Dn: downstream 
Fig. 9. Leiognathus equulus. Catches in open (black bars) and closed (grey bars) systems in $102 \mathrm{~mm}$ mesh nets: (a) mean catch rates with $95 \%$ CI by sampling site; (b) total catch by length class. FL: fork length; Up: upstream; Dn: downstream

Fig. 10. Liza vaigiensis. Catches in open (black bars) and closed (grey bars) systems in $102 \mathrm{~mm}$ mesh nets: (a) mean catch rates with $95 \%$ CI by sampling site; (b) total catch by length class. FL: fork length; Up: upstream; Dn: downstream

Fig. 11. Polydactylus macrochir. Catches in open (black bars) and closed (grey bars) systems: (a) mean catch rates with $95 \%$ CI by sampling site for $152 \mathrm{~mm}$ mesh nets; (b) total catch by length class for $152 \mathrm{~mm}$ mesh nets; (c) mean catch rates with $95 \%$ CI for $102 \mathrm{~mm}$ mesh nets; (d) total catch by length class for $102 \mathrm{~mm}$ mesh nets. FL: fork length; Up: upstream; Dn: downstream
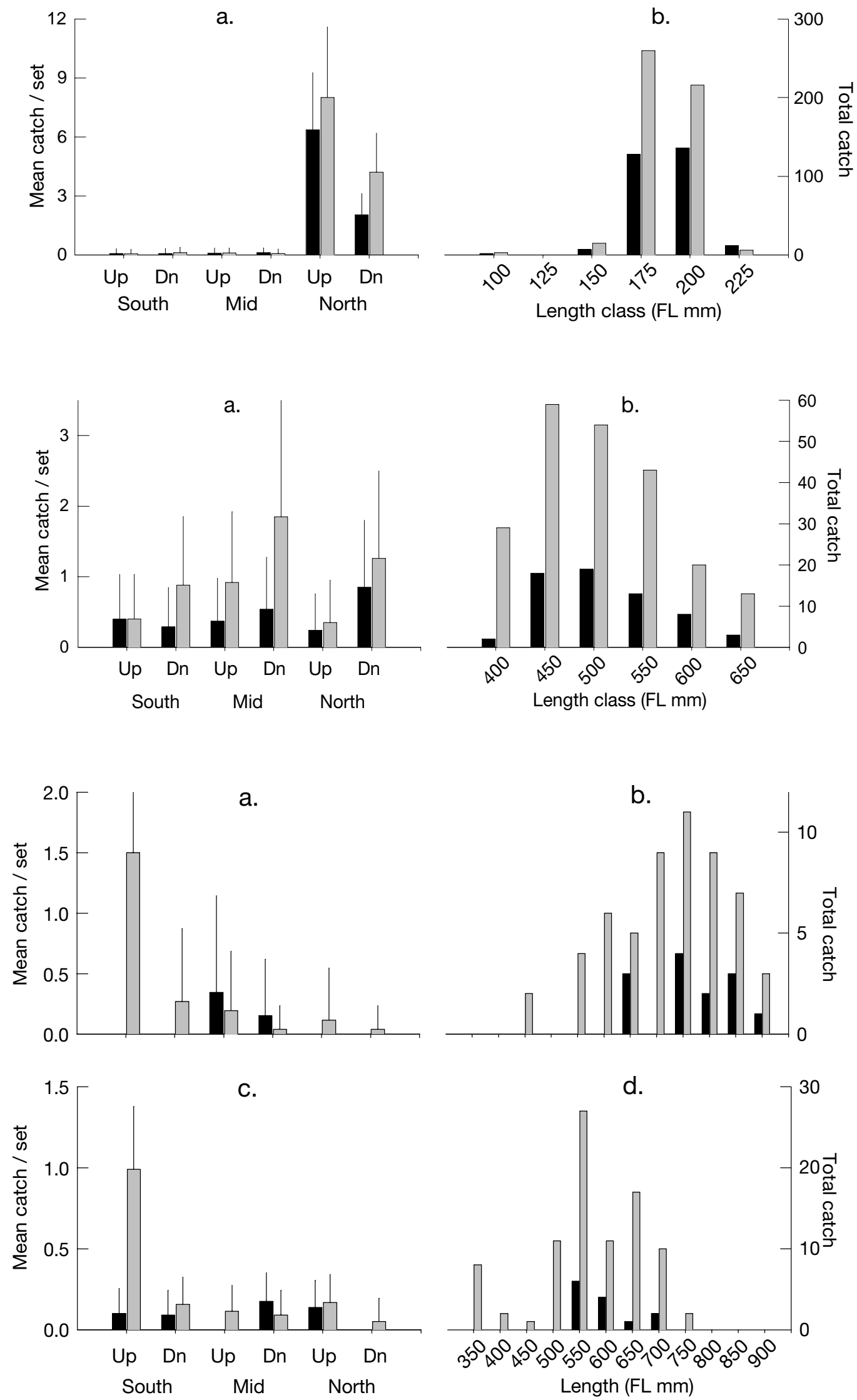

d.

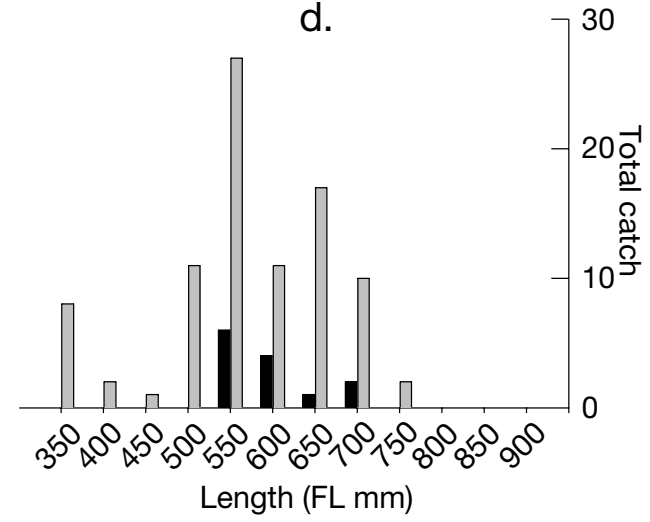


Table 4. Results of Mann-Whitney $U$-tests for differences in median fish length $(\mathrm{L}, \mathrm{mm})$ between areas closed and open to net fishing. Significantly greater values: ${ }^{*} \mathrm{p}<0.05 ;{ }^{* * *} \mathrm{p} 0.001$

\begin{tabular}{|lrcrc|}
\hline \multirow{2}{*}{ Species } & \multicolumn{2}{c}{ Open } & \multicolumn{2}{c|}{ Closed } \\
& $\mathrm{n}$ & $\begin{array}{c}\mathrm{L} \\
\mathrm{(mm})\end{array}$ & $\mathrm{n}$ & $\begin{array}{c}\mathrm{L} \\
(\mathrm{mm})\end{array}$ \\
\hline Eleutheronema tetradactylum & 229 & 305 & 462 & $420^{* * *}$ \\
Lates calcarifer & 430 & 495 & 1226 & $530^{* * *}$ \\
Scomberoides commersonianus & 76 & 388 & 290 & $467^{* * *}$ \\
Liza vaigiensis & 63 & 481 & 218 & 470 \\
Polydactylus macrochir & 26 & 630 & 146 & 602 \\
Pomadasys argenteus & 94 & 295 & 190 & 292 \\
Pomadasys kaakan & 158 & $320^{*}$ & 194 & 315 \\
\hline
\end{tabular}

\section{DISCUSSION}

\section{Comparison of catch rates}

Total abundance, biomass and diversity were greater in systems closed to commercial net fishing for catch in the 2 largest-mesh research nets (152 and $102 \mathrm{~mm}$ mesh). Catch rates of 5 species were substantially and systematically greater in closed systems, including the bycatch species Carcharhinus leucas and 4 species which are marketed: Lates calcarifer and Scomberoides commersonianus (for both 152 and $102 \mathrm{~mm}$ nets), and Liza vaigiensis and Polydactylus macrochir (for $102 \mathrm{~mm}$ mesh nets). These trends were largely consistent among 3 geographically distant regions with differing environmental conditions, and in 2 ecologically distinct sectors of each system (upstream and downstream). As regulations allowed fishers to set gill nets of 150 to $215 \mathrm{~mm}$ stretched mesh in estuaries open to commercial fishing, depletion by fishing operations is the most likely factor to explain the lower catch rates in open rivers sampled using $152 \mathrm{~mm}$ research nets.

Lower numbers obtained by using $102 \mathrm{~mm}$ mesh nets cannot be as readily attributed to gill netting operations directly within systems surveyed in this study. Although commercial fishing with set gill nets having mesh sizes $<150 \mathrm{~mm}$ has been prohibited for over $10 \mathrm{yr}$ within all riverine estuaries, significantly lower catch rates occurred for the $102 \mathrm{~mm}$ nets in open systems for both total abundance and for 4 of the marketed species (Lates calcarifer, Scomberoides commersonianus, Liza vaigiensis and Polydactylus macrochir). There are several possible explanations for this finding. Firstly, commercial fishing with set gill nets having smaller mesh sizes (100 mm minimum) has been permitted along the foreshores adjacent to the estuary mouths for over $10 \mathrm{yr}$. Mainly targeting blue threadfin Eleutheronema tetradactylum, this fishing practice was generally allowed whether the adjacent system itself was closed or open to commercial net fishing. However, to an unknown degree, commercial use of these finer mesh foreshore nets may have been more prevalent near open than closed estuaries, perhaps due to cost effectiveness when carried out in conjunction with fishing operations in the systems that were open to gill net fishing. As identified in concurrent fishery-dependent surveys, common bycatch species netted in commercial operations along foreshores include 3 of the 4 species that had lower catch rates in open rivers sampled in the current study: S. commersonianus, $L$. vaigiensis and P. macrochir (Halliday et al. 2001). In addition, very limited commercial use of haul seines with finer mesh sizes (50 mm minimum) was permitted in rivers open to net fishing. These operations targeted schools of mullet, and thus may also have contributed to the relatively lower catch rates of some species (e.g. L. vaigiensis) caught by the research teams in commercially fished rivers.

Another factor influencing catch rates in the $102 \mathrm{~mm}$ mesh nets was evident in the overlap between size classes of polynemids caught in multiple net types. For king threadfin Polydactylus macrochir, the same size class (500 to $700 \mathrm{~mm}$ ) dominated catch in both the 102 and $152 \mathrm{~mm}$ nets (Fig. 11). Thus, $150 \mathrm{~mm}$ mesh gill nets used by commercial fishers within open rivers may also catch substantial numbers of smaller king threadfin. Species in the family Polynemidae may be particularly vulnerable to encounters with set nets of any mesh size (Stanger 1974). Threadfin either died or swam away in a noticeably weakened condition after release from our research nets.

Since barramundi recruitment into river systems depends largely on successful spawning of highly localized populations (Davis 1986), another important factor that may have influenced catch rates in $102 \mathrm{~mm}$ mesh research nets applies chiefly to this species. Barramundi are protandrous hermaphrodites that mature as males at about 620 to $650 \mathrm{~mm}$ (Year 4; Williams 1997). By 900 mm (Year 7) most have transformed from male to female (Davis 1986). In addition to minimum size limits of $580 \mathrm{~mm}$ on the Queensland east coast, maximum legal size limits of $1200 \mathrm{~mm}$ were in effect (i.e. to protect large females; Williams 1997). Furthermore, seasonal closures for harvesting barramundi were imposed during the period of predicted barramundi spawning (Fisheries Act 1994). However, since 60 to $70 \%$ of the barramundi harvested commercially are thought to be immature at capture, raising the minimum size would reduce the number of immature barramundi caught (Williams 1997). Such action may generate a more sustainable fishery by helping to reduce the apparent gap between populations in open and closed estuaries, indicated by the results of the current study. 
Another possible consideration is that our study design was inherently flawed. We may have inadvertently selected a set of closed sites in 3 systems that consistently provided superior habitat compared with the open sites. This implies that our catch rates in all nets would have been lower in open systems, even in the absence of commercial fishing pressure. However, this was not the case since differences between open and closed sites were not found for the majority of fish families netted (Table 1). Furthermore, although comprehensive surveys of habitat features are not currently available for these systems, preferences regarding food, cover and physical conditions are likely to differ among species that had significantly higher abundances in the closed rivers (Carcharhinus leucas, Polydactylus macrochir, Lates calcarifer, Liza vaigiensis and Scomberoides commersonianus). For example, in terms of food habits, king threadfin are bottom-feeders, locating food organisms such as prawns and crabs in muddy substrates with free filaments of their highly modified pectoral fins (Grant 1995). In contrast, queenfish consume mainly pelagic fish (Salini et al. 1998), and diamondscale mullet school just below the surface, consuming detritus and algae (FishBase). Diets of barramundi vary, depending on their size. When they are smaller (200 to $400 \mathrm{~mm}$ ) they generally consume demersal crustaceans, and fish when they reach greater sizes (>400 mm; Davis 1985). Thus, habitat features are not likely to account for systematically lower catch rates in systems open to commercial net fishing.

\section{Biodiversity effects}

Potential effects of net fishing operations on estuarine ecosystems and biodiversity include: (1) changes in habitat due to physical disturbance associated with fishing operations; (2) bycatch-i.e. catch in commercial operations that is discarded; (3) changes in the balance between numbers of predators and their prey; (4) changes in competitive interactions among species; and (5) changes in emergent properties including diversity and community structure.

(1) Although comprehensive surveys were not conducted, no habitat damage due to physical disturbance associated with fishing operations was observed. While trawls and other gear types are known to have destructive effects, set gill nets are less likely to cause habitat damage (Halliday et al. 2001).

(2) Reduced numbers of one bycatch species, Carcharhinus leucas, occurred in rivers open to net fishing. C. leucas females are livebearers that give birth at the mouths of estuarine rivers throughout the tropics (Compagno 1984). Newborn sharks generally proceed to upstream habitats and their morphology and size at birth (550 to $800 \mathrm{~mm}$, Last \& Stevens 1994) appear to make these sharks vulnerable to large mesh gillnets. C. leucas caught in our research nets were presumably juveniles in their first year of life (650 to $800 \mathrm{~mm}$ ).

(3) Of species having reduced numbers in open systems (Liza vaigiensis, Carcharhinus leucas, Lates calcarifer, Polydactylus macrochir, and Scomberoides commersonianus), all but mullet $L$. vaigiensis are upper level consumers. Since they comprised about onethird of the fishes caught in the larger mesh nets, it seems likely that removing substantial numbers of these predators would have had an impact on abundances of their prey (Hall 1999). Any effects of relatively greater predation levels in closed systems should have been evident in the surveys due to differences in numbers of barramundi alone; $91 \%$ of barramundi caught in our research nets were in larger size classes and likely to be mainly piscivorous. Fishes that barramundi consume are most likely to be engraulids, clupeids, mugilids, and ariids (Davis 1985), the same taxa that were most abundant in our small mesh nets. Thus, according to the trophic cascade paradigm, greater abundances should have been netted in open systems using finer mesh nets $(51 \mathrm{~mm}$ and multipanel 19/25/32 mm mesh). However, we found no evidence that prey numbers were greater in open systems. Furthermore, species composition did not systematically differ between open and closed systems. In several studies of coral-reef fish communities, results were similar to ours: reduced abundances of piscivorous species targeted by fishers did not correspond with any notable changes in prey populations (see review in Jennings \& Kaiser 1998). However, in freshwater systems, strong cascading effects from top predators to lower trophic levels have been empirically demonstrated (Carpenter et al. 1985, Power 1990). Apparently the indirect effects of fishing on coral reef and tropical estuarine fish communities are smaller and less consistent than they are in strictly freshwater systems. Perhaps the difference in numbers of predators between open and closed systems was not great enough to generate detectable differences in relative abundances of their main prey (i.e. top-down effects). Independently of predation, numbers of short-lived planktivorous fishes capable of rapid recruitment such as clupeids and engraulids may be more closely linked with availability of their food supply, mainly zooplankton (Robertson \& Duke 1990, McKinnon \& Klumpp 1998). Similarly, scavengers and detritivores such as ariids and mugilids are likely to encounter abundant food resources in estuaries (Day et al. 1989). Thus, contrary to our original hypothesis, the number of predators removed by commercial net fishing did not measurably effect prey abundance levels. 
(4) Our study found no evidence that depletion of target and bycatch species by fishing led to increases in numbers of their competitors. In estuaries, toplevel consumers tend to be opportunistic and have overlapping diets (McHugh 1967). For example, among the species of barramundi competitors, 4 were sufficiently abundant for statistical comparison between open and closed systems: Arius sp., Pomadasys argenteus, P. kaakan, Eleutheronema tetradactylum, and the sciaenid Nibea soldado. However, none of these species was consistently more abundant in open rivers. Other competitor taxa (e.g. sphyraenids, platycephalids, lutjanids, sparids and serranids) were not sampled in large enough numbers for statistical analysis. Despite this lack of data, our results appear consistent with views expressed in a major recent review of published studies on effects of fishing by Jennings \& Kaiser (1998). Based on relevant studies in a range of marine ecosystems (but not including estuaries), these authors concluded that compensatory species replacements seldom occur in response to fishing a particular species guild. Thus, our results may be interpreted as supporting and extending this conclusion for Queensland's tropical estuaries.

(5) The current study is one of the first to provide a comparison of several discrete estuarine systems sampled simultaneously (i.e. 6 systems within a $7 \mathrm{~d}$ period per trip) under highly standardized procedures (i.e. repeated use of the same crews, gear, tidal conditions, sites, and procedures). As indicated by the occurrence of 141 species sampled overall, with only 17 species in common among all 12 study sites, these estuarine systems have a high level of diversity, both within and between the systems. Thus, our study results provide unique insights into the complex spatial and temporal patterns existing simultaneously in a series of estuarine systems within a tropical region. Perhaps this high level of complexity and diversity explains why we detected no effects on numbers and composition of lower trophic levels despite substantial depletion of top predators by commercial fishing. Marine ecosystems are said to be well adapted to fluctuations in component species (Jennings \& Kaiser 1998). Similarly, in certain estuarine systems, a high level of diversity may stabilise populations against perturbations. The presence of mangrove shorelines may enhance diversity and stability of estuarine systems in tropical and subtropical regions (Halliday \& Young 1996, Sheaves 1998). Well-developed mangrove habitats may also function as nursery grounds for juveniles of coral-reef associated species potentially enhancing biodiversity of both reef- and mangrove-dominated systems (Ley \& McIvor 2002).

\section{Value of long term protection for estuarine areas}

This study addressed one of the main questions involving integration of fisheries and ecosystems management objectives: What happens to biota in reserves protected from the commercial harvest of fish? The effectiveness of marine reserves has received much attention in recent ecological and fishery management literature (Bohnsack 1993, Allison et al. 1998, Lauck et al. 1998, Murray et al. 1999). Empirical evidence from several case studies demonstrates that reserves can harbor more diversity, higher abundance, and notably different community structures (see Allison et al. 1998). Because we were able to show differences in abundance for most target and bycatch species among replicate protected estuaries, our results significantly strengthen the case in favour of non-commercial reserves for achieving stock-protection objectives. Protected estuaries in tropical Queensland may serve as refugia for critical components of populations subject to exploitation. For populations of Lates calcarifer, the main target species in these estuarine systems, more spawners may survive within reserves, resulting in greater overall egg production. If the reserves contain suitable habitat, more juveniles may reach a reproductive age. This process may not only maintain the level of recruitment to the non-commercial fishery within the reserve, but may also spill over to areas outside the closure as shown from tagging experiments in other systems (Johnson et al. 1999, Roberts et al. 2001). Previous tagging studies in the study area have identified migration of individual barramundi between discrete estuarine systems (Russell \& Garrett 1988, Helmke et al. 1999, Lunow \& Garrett 1999). Although tagging experiments were not conducted as part of the current study, $20 \%$ of tagged barramundi that were coincidentally captured in our surveys came from distant river systems (Halliday et al. 2001).

\section{Conclusions}

To our knowledge, these findings represent the first published scientific evidence evaluating the effects of closed areas on fish communities at a broad range of trophic levels in multiple tropical estuaries. This study encompassed a wide range of habitat and environmental conditions with different associated fish communities. Riverine estuaries open to commercial net fishing had lower diversity, biomass and relative abundance of larger predatory fishes than comparable systems closed to commercial netting. Relative abundances and biodiversity at lower trophic levels did not appear to be influenced by these differences in abundances at higher trophic levels. This study clearly demonstrates 
both the value of reserves in protecting populations of exploited fish in estuaries and the viability of assessing the effects of fishing through comparison of paired fished and unfished systems.

Acknowledgements. The Australian Fisheries Research and Development Corporation, FRDC Project No. 97/206, funded this project. We would like to thank the reviewers of the manuscript for their very useful comments and suggestions. Many colleagues deserve recognition for their significant contributions to the project, especially P. Dixon, R. Partridge, S. Boyle, A. Caldwell, A. Blair, C. Truscott, K. Ray, I. Ashworth, M. Cappo, D. James, T. McKenna, P. Speare, M. Vaughan, D. Fenner and V. Veitch.

\section{LITERATURE CITED}

Allen GR (1997) Marine fishes of the Great Barrier Reef and Southeast Asia. A field guide for anglers and divers. Western Australian Museum, Perth

Allison GW, Lubchenco J, Carr MH (1998) Marine reserves are necessary but not sufficient for marine conservation. Ecol Appl 8(1)Suppl:S79-S92

Blaber SJM, Albaret JJ, Ching CV, Cyrus DP and 7 others (2000) Effects of fishing on the structure and functioning of estuarine and near shore ecosystems. ICES J Mar Sci 57(3):590-602

Bohnsack JA (1993) Marine reserves: they enhance fisheries, reduce conflicts, and protect resources. Oceanus 1993: 63-71

Carpenter SR, Kitchell JF, Hodgson JR (1985) Cascading trophic interactions and lake productivity: fish predation and herbivory can regulate lake ecosystems. BioScience 35(10):634-639

Clarke KR, Warwick RM (1994) Change in marine communities: an approach to statistical analysis and interpretation. PRIMER-E. Plymouth Marine Laboratory, Plymouth

Compagno LJV (1984) FAO Species catalogue, Vol 4. Sharks of the world. An annotated and illustrated catalogue of sharks species known to date. Food and Agriculture Organisation, Rome

Davis TLO (1985) The food of barramundi, Lates calcarifer (Bloch), in coastal and inland waters of Van Dieman Gulf and the Gulf of Carpentaria, Australia. J Fish Biol 26: $669-682$

Davis TLO (1986) Biology of wildstock Lates calcarifer in northern Australia. In: Copland JW, Grey DL (eds) Management of wild and cultured sea bass/barramundi (Lates calcarifer). Australian Centre for International Agricultural Research, Brisbane, p 22-29

Day JW Jr, Hall CAS, Kemp WM, Yanez-Arancibia A (1989) Estuarine ecology. John Wiley \& Sons, Brisbane

Grant EM (1997) Guide to fishes. EM Grant PTY, Redcliff, Queensland

Greenhouse SW, Geiser S (1959) On methods in the analysis of profile data. Psychometrika 32(3):95-112

Hall S (1999) The effects of fishing on marine ecosystems and communities. Blackwell Science, London

Halliday IA, Young WR (1996) Density, biomass and species composition of fish in a subtropical Rhizophora stylosa mangrove forest. Mar Freshw Res 47:609-615

Halliday IA, Ley JA, Tobin AJ, Garrett RN, Gribble NA, Mayer DA (2001) The effects of net fishing: addressing biodiversity and bycatch issues in Queensland inshore waters. Fisheries Research and Development Corporation 97/206 (Canberra, ACT), Australian Institute of Marine Science, and Queensland Department of Primary Industries, Deception Bay, Queensland

Helmke SA, Peverell SC, Garrett RN (1999). Fisheries Resources of Trinity Inlet, Queensland. Queensland Department of Primary Industries, Cairns

Jennings S, Kaiser MJ (1998) The effects of fishing on marine ecosystems. Adv Mar Biol 34:203-352

Johnson DR, Funicelli NA, Bohnsack JA (1999) Effectiveness of an existing estuarine no-take fish sanctuary within the Kennedy Space Center, Florida. N Am J Fish Manage 19: 436-453

Lauck TC, Clark W, Mangel M, Munro GR (1998) Implementing the precautionary principle in fisheries management through marine reserves. Ecol Appl 8(1)Suppl: S72-S78

Ley JA, McIvor CC (2002) Linkages between estuarine and reef fish assemblages: enhancement by the presence of well-developed mangrove shorelines. In: Porter JW, Porter KG (eds) The Everglades, Florida Bay, and coral reefs of the Florida Keys: an ecosystem sourcebook. CRC Press, Boca Raton, FL, p 539-562

Lunow CP, Garrett RN (1999) The fisheries resources of the Bohle River, Queensland. Queensland Department of Primary Industries, Cairns

McHugh JL (1967) Estuarine nekton. In: Lauff GH (ed) Estuaries. American Association for the Advancement of Science, Washington, DC, p 581-620

McKinnon AD, Klumpp DW (1998) Mangrove zooplankton of north Queensland, Australia. Hydrobiologia 362: $127-143$

Milton DA, Die D, Tenakanai C, Swales S (1998) Selectivity for barramundi (Lates calcarifer) in the Fly River, Papua New Guinea: implications for managing gill-net fisheries on protandrous fishes. Mar Freshw Res 49:499-506

Munro ISR (1967) The fishes of New Guinea. Australian Government Printer, Sydney

Murray SN, Ambrose RF, Bohnsack JA, Botsford LW and 15 others (1999) No-take reserves: sustaining fishery populations and marine ecosystems. Fisheries 24 (11) 11-25

Nelson JS (1994) Fishes of the world. John Wiley \& Sons, New York

Pauly DV, Christensen C, Walters C (2000) Ecopath, Ecosim and Ecospace as tools for evaluating ecosystem impact of fisheries. ICES J Mar Sci 57(3):697-706

Payne RW, Lane PW, Digby PGN, Harding SA and 7 others (1993) Genstat 5, release 3 reference manual. Clarendon Press, Oxford

Power ME (1990) Effects of fish in river food webs. Science 250:811-814

Power ME, Matthews WJ, Stewart AJ (1985) Grazing minnows, piscivorous bass, and stream algae: dynamics of a strong interaction. Ecology 66(5):1448-1456

Randall JE, Allen GR, Steene RC (1997) Fishes of the Great Barrier Reef and Coral Sea. Crawford House, Bathurst, NSW

Roberts CM, Bohnsack JA, Gell F, Hawkins JP, Goodridge R (2001) Effects of marine reserves on adjacent fisheries. Science 294:1920-1923

Robertson AI, Duke NC (1990) Recruitment, growth and residence time of fishes in a tropical Australian mangrove system. Estuar Coast Shelf Sci 31:723-743

Russ GR, Alcala AC (1989) Effects of intense fishing pressure on an assemblage of coral reef fishes. Mar Ecol Prog Ser 56:13-27 
Russell DJ, Garrett RN (1988) Movements of juvenile barramundi, Lates calcarifer (Bloch), in north-eastern Queensland. Aust J Mar Freshw Res 39:117-123

Sainsbury KJ, Punt AE, Smith ADM (2000) Design of operational management strategies for achieving fishery ecosystem objectives. ICES J Mar Sci 57(3):731-741

Salini JP, Brewer DT, Blaber SJM (1998) Dietary studies on the predatory fishes of the Norman River estuary, with particular reference to penaeid prawns. Estuar Coast Shelf Sci 46(6):837-847

Sheaves M (1998) Spatial patterns in estuarine fish faunas in tropical Queensland: a reflection of interaction between long-term physical and biological processes? Mar Freshw Res 49:31-40

Stanger JD (1974) A study of the growth, feeding and reproduction of the threadfin, Eleutheronema tetradactylum

Editorial responsibility: Charles Birkeland (Contributing Editor), Honolulu, Hawaii, USA
(Shaw). BSc thesis, James Cook University of North Queensland, Townsville

Statsoft (1995) STATISTICA for Windows. Microsoft, Tulsa, OK

Wantiez L, Thollot P, Kulbicki M (1997) Effects of marine reserves on coral reef fish communities from 5 islands in New Caledonia. Coral Reefs 16:215-224

Williams LE (1997) Queensland's fisheries resources: current condition and recent trends, 1988-1995. Queensland Department of Primary Industries, Brisbane

Worm B, Lotze HK, Hillebrand H, Sommer U (2002) Consumer versus resource control of species diversity and ecosystem functioning. Nature 417:848-851

Yamamura K (1999) Transformation using $(x+0.5)$ to stabilize the variance of populations. Res Pop Ecol 41:229-234

Zar JH (1999) Biotatistical analysis, 4th edn. Prentice Hall, Englewood Cliffs, NJ

Submitted: April 8, 2001; Accepted: July 25, 2002

Proofs received from author(s): November 21, 2002 